\title{
ANÁLISE DOS CONCEITOS DE IDEOLOGIA, DISCIPLINA E HABITUA A PARTIR DA MASSIFICAÇÃO DO ESPORTE NO BRASIL $^{1}$
}

\author{
Valentina Iragola Cairoli ${ }^{2}$
}

- Enviado em 18/04/2016

- Aprovado em 20/05/2016

\section{RESUMO}

O esporte - ou seja, o treinamento do corpo - encarna valores como a disciplina, a energia e o ritmo; valores que podem ser identificados na promoção da produtividade econômica. A partir da segunda metade do século XX, em um contexto de industrialização e urbanização do país, a atividade esportiva começa a se transformar em um fenômeno massivo de consumo no tempo livre. Nas grandes cidades do país, especialmente Rio de Janeiro e São Paulo, a atividade esportiva transforma-se numa marca distintiva de caráter modernizador, voltadas à representações e aos padrões de higiene e saúde que foram absorvidas por vários setores da sociedade.

O trabalho segui o objetivo principal de problematizar a institucionalização da educação física como disciplina obrigatória no ensino médio, assim como debater a respeito do processo de massificação das práticas esportivas nos contextos urbanos do país. Coloca-se como segundo objetivo, apresentar e discutir, a partir do fenômeno exposto, os alcances e limitações do conceito de ideologia. Nesse sentido, apresentaremos as propostas teóricas de Thompson a respeito da ideologia e os meios de comunicação, o conceito de habitus de Bourdieu e de disciplina de Foucault.

Palavras-chave: Esporte, Ideologia, Disciplina, Habitus.

\section{INTRODUÇÃO}

Os intuitos são muitos; as práticas, diversas. De um lado uns jogam vôlei nas areias. Ao lado, outros armam uma rede de peteca, enquanto muitos correm e fazem exercícios, acompanhados ou sós, espontaneamente ou sob a orientação de um professor (hoje, chamado pelo pomposo título de personal trainer). A balbúrida dos que jogam futebol e basquete contrasta com a postura de tenistas que tentam se concentrado em meio ao barulho. Em uma quadra, idosos fazem uma aula de ginástica; na grama, há uma atividade de ioga. Na pista que margeia a praia, bicicletas dos mais diferentes formatos e pedestres

\footnotetext{
${ }^{1}$ Uma versão preliminar desse trabalho foi apresentada no GT1: INSTITUIÇÕES E PODER: PARENTESCOS E GENEALOGIAS do VII Seminário Nacional de Sociologia e Política da UFPR realizado de 11 a 13 de maio de 2016 em Curitiba.
}

2 Aluna regular do mestrado em Sociologia, PPGS, UFSCar. Licenciada em Sociologia pela Universidad de la República (UdelaR), Montevideo, Uruguay. O artigo é resultado do trabalho final apresentado à Prof. Dra. Rosemeire A. Scopinho, referente à disciplina de Sociologia dos Processos de Subjetivação. Endereço eletrônico: viragola@gmail.com 
com as mais distintas roupas disputam o espaço entre si. (ANDRADE DE MELO, 2011, p. 506)

Na narração acima, o autor descreve o cenário de uma manhã no parque urbano Aterro do Flamengo, no Rio de Janeiro. A imagem ilustra o fenômeno a respeito do qual queremos refletir neste trabalho, a massificação ${ }^{3}$ do que o mesmo autor denomina como "jeito de ser esportivo". Tal "jeito de ser" tem a ver com a construção de uma nova relação com o próprio corpo ${ }^{4}$, construção que conduz a uma transformação ao nível dos sentimentos. Na conformação dessa nova subjetividade que se estrutura no país a partir das últimas décadas do século XVIII, converge uma série de mudanças articuladas entre si: o desenvolvimento do modo de produção fabril, o crescimento das cidades, a emergência da burguesia e do operariado como classes sociais, a valorização da tecnologia, o desenvolvimento do pensamento científico (e com isso a redução de injunções de natureza religiosa), a estruturação de uma indústria do entretenimento e a configuração da imagem e do espetáculo como noções fundamentais na estruturação do novo modo de vida (ANDRADE DE MELO, 2011).

A partir do exposto, a proposta deste trabalho consiste em refletir a respeito do caráter massivo que tem tomado o esporte nos contextos citadinos do Brasil e, com isso, na conformação do novo sujeito urbano, aquele que adota o jeito de vida esportivo. Nessa linha, apresentaremos diferentes abordagens teóricas que têm como qualidades em comum, além de serem consideradas referências na teoria sociológica contemporânea, apresentar propostas de síntese analítica entre as estruturas e a conformação do sujeito. Referimo-nos às propostas de Foucault sobre a conformação do sujeito disciplinado, à conformação do habitus em Bourdieu e à noção de ideologia no contexto de mediação da cultura moderna abordada por Thompson. Mas antes abordaremos os pressupostos de Marx a respeito do conceito de Ideologia e corpo, na medida em que o consideramos referência na discussão dos três autores.

\section{IDEOLOGIA EM MARX}

"[...] não é a consciência dos homens que determina seu ser, ao contrário, é o seu ser social que determina sua consciência" (MARX, 2008, p. 47)

\footnotetext{
${ }^{3}$ Utilizamos o termo massificação no sentido exposto por J. Thompson (1990), ou seja, no sentido de ser disponível a uma ampla pluralidade de receptores.

${ }^{4}$ Como expõe Andrade de Melo no mesmo texto, o corpo que outrora era motivo de vergonha e restrições, torna-se paulatinamente elemento de consumo, sendo mais exposto e sujeito a novas normas de comportamento.
} 
Imaginemos por um momento uma pessoa realizando um exercício físico e analisemos os movimentos para perceber do que falamos quando dizemos treino esportivo. Seguramente, a pessoa vai fazer um movimento rítmico, reiterado durante um período de tempo prolongado. Nesse sentido, podemos notar que o treino consiste sempre numa relação ótima entre estímulo e descanso; trata-se de uma relação correspondente a um modelo cíclico, que separa o treino em espaços de tempo e que tem como objetivo permitir ao corpo se adaptar a condições de estresse às quais é submetido. No treino esportivo, o corpo é percebido como objeto operacionalizável, ou seja, como máquina que pode ser dividida em partes e funções, da qual podem se extrair ações também divididas em lapsos de tempo rítmicos. Nesta perspectiva, o corpo se maquiniza, é reconhecido como objeto cujo rendimento pode ser sempre melhor, para o qual é submetido a um conjunto de ações orientadas nessa direção (FERNANDEZ VAZ, 1999).

Se pensamos, por outro lado, no corpo de um homem trabalhando nos albores da Revolução Industrial, nos albores do sistema fabril, podemos imaginar movimentos similares, movimentos rítmicos e repetitivos. Tomando o referente teórico proposto por Marx, devemos, então, procurar as raízes do que hoje conhecemos como treinamento esportivo nas relações produtivas do sistema capitalista.

Para Marx, os modos de pensar, assim como todo o aparato institucional que o sustenta, têm raízes na base econômica. Os indivíduos, seus pensamentos, suas consciências, são condicionados pelas relações sociais e produtivas nas quais se encontram imersos. Nas palavras do autor, "na produção social da própria experiência, os homens entram em relações determinadas, necessárias, independentes de sua vontade; essas relações de produção correspondem a um grau determinado de desenvolvimento de suas forças produtivas" (MARX, 2008, p. 47). A consciência individual constrói-se a partir da posição nas relações de produção, o que significa, a nível estrutural, que o mundo das ideias depende (em última instância) da base econômica; e, por outro lado, que o mundo individual, a consciência dos homens, encontra-se condicionado pelas relações nas quais se encontra imerso. Para explicar as formas de pensar dos homens, seus costumes e estilos de vida, temos de atender às relações econômicas às quais eles estão integrados.

Essa concepção de ideologia que podemos identificar na Contribuição à crítica da economia política é categorizada por Thompson (1990) como epifenomênica, entendida como sistema de ideias que expressa os interesses da classe dominante, representando as relações de classe de forma ilusória. A ideologia, nesse sentido, toma a forma das ideias que num período histórico articulam as ambições e interesses dos grupos dominantes. Nesta linha de raciocínio, no esporte e nos valores 
encarnados nele, como a disciplina, a energia e o ritmo, podemos encontrar representados os ideais da promoção da produtividade econômica. É nesse sentido que Torri (2008) vai afirmar que o esporte constitui o representante ideológico do capitalismo, expressando os interesses da classe dominante da época.

Podemos identificar na Europa do século XIX, no contexto da dupla revolução, industrial e política, as raízes do pensamento do que vai se constituir como a Educação Física.

Na consolidação dos ideais da Revolução Burguesa, a Educação Física se ocupará de um corpo a-histórico, indeterminado, um corpo anátomo-fisiológico, meticulosamente estudado e, cientificamente explicado. Ele negará o funambulismo, os acrobatas, a especulação e buscará as explicações para o seu preceder na visão de ciência hegemônica na sociedade burguesa: a visão positiva da ciência (SOARES, 1994, p. 10).

Nesse contexto de revolução, o sujeito, em atenção às necessidades do novo sistema econômico em desenvolvimento, vai ser recriado, e a ciência ocupará um papel substancial nessa construção. O predomínio do pensamento positivista vai ter como consequência a consolidação do homem como centro de um modelo mecanicista e organicista, que buscara encontrar leis universais para seguir o caminho rumo a evolução, a partir, sobretudo, das grandes comparações. Nesse contexto, o Estado e os profissionais da medicina vão constituir os agentes centrais, questão sobre a qual nos aprofundaremos a seguir.

\section{O DISCIPLINAMENTO DO CORPO EM FOUCAULT}

Se a exploração econômica separa a força e o produto de trabalho, digamos que a coerção disciplinar estabelece no corpo o elo coercitivo entre uma aptidão dominada e uma dominação acentuada" (FOUCAULT, 1987, p. 127).

Continuemos, agora, no caminho de analisar e pensar as raízes do que hoje conhecemos como um estilo de vida esportivo. Em consonância com o que dissemos antes, a Educação Física surge nas últimas décadas do século XIX, como resultado de um contexto que vem gestando-se já desde finais do século anterior, no marco do desenvolvimento do pensamento positivista, incorporando e veiculando ideias de hierarquia e de ordem. No centro dessa filosofia encontra-se um homem agora biologizado; na medida que o social adquire uma forma orgânica de ser pensada, também o homem vai ser construído em termos orgânicos, em termos biológicos (SOARES, 1994).

A Europa do início do século XIX assiste ao nascimento e desenvolvimento de um conjunto de saberes profissionais que dominam o conhecimento sobre o corpo biologicamente concebido, assim como de uma variedade de práticas que passam, através dele, a intervir na sociedade. Esse 
desenvolvimento dos saberes profissionais tem a ver com o que Foucault identifica como uma nova forma de exercício do poder, uma nova mecânica que alcança os indivíduos, seus corpos, gestos, atitudes e discursos. Em outras palavras, suas vidas cotidianas. Nas palavras do autor (1984, p. $145)$ :

O domínio, a consciência de seu próprio corpo só puderam ser adquiridos pelo efeito do investimento do corpo pelo poder: a ginástica, os exercícios, o desenvolvimento muscular, a nudez, a exaltação do belo corpo... tudo isto conduz ao desejo de seu próprio corpo através de um trabalho insistente, obstinado, meticuloso, que o poder exerceu sobre o corpo das crianças, dos soldados, sobre o corpo sadio.

$\mathrm{Na}$ conformação do homem-corpo, do homem-organismo, a medicina teve um papel substancial. Afinado com o desenvolvimento do capitalismo, o corpo saudável transforma-se numa necessidade. E, nesse sentido, será desenvolvido um conjunto de políticas de saúde, que vão desde a educação obrigatória de condutas de higienização pessoal e formação de hábitos morais até o desenvolvimento de uma polícia técnica e de uma grande engenharia sanitária.

Os discursos e práticas médicas, higienistas e com um forte caráter moralizador serão constituídos como instrumentos de intervenção da sociedade, da vida cotidiana dos indivíduos, alterando hábitos, costumes, crenças e valores. Os Estados vão iniciar um enorme processo de reorganização das sociedades, para o qual resulta substancial o surgimento da disciplina, entendida como uma anatomia política que olha para o detalhe. Em palavras do autor (FOCAULT, 1987, p.129),

A minúcia dos regulamentos, o olhar esmiuçante das inspeções, o controle das mínimas parcelas da vida e do corpo darão em breve, no quadro da escola, do quartel, do hospital ou da oficina, um conteúdo laicizado, uma racionalidade econômica, ou técnica a esse cálculo místico do ínfimo e do infinito.

Operando frente a uma distribuição quadricular dos indivíduos no espaço, uma vigilância hierárquica que controla todos os detalhes da atividade, acompanhada de uma sanção ${ }^{5}$ tendente sempre a normalizar os comportamentos e, com isso, à instauração do exame como rotina, formam uma economia tendente a extrair dos corpos o máximo de força e utilidade possível, ao custo da redução dos tempos e movimentos inúteis.

Como expõe Soares, no último quartel do século XIX, na Europa, e como veremos a seguir também no Brasil, o Estado vai consolidar um processo de extensão da escolarização primária e dos

\footnotetext{
${ }^{5}$ A sanção, nos trabalhos de Foucault, é compreendida não só em termos negativos, mas em termos de punição e gratificação, tendente a conduzir as condutas, os gestos e pensamentos a padrões normalizados.
} 
serviços de saúde. E, dentro desse quadro, e como forma disciplinar voltada ao corpo biológico, carregada de conteúdo médico e higienista, a Educação Física chega aos foros científicos. Num contexto no qual a educação começa a ter a conotação de meio de ascensão social, o exercício físico vai se constituir como política de educação escolar, e assim, nas palavras da autora (1994, p. 95), "tempo e espaço, conteúdo e forma foram pensados. O estudo, o descanso, o exercício físico, a alimentação... tudo passou a ser regulado, controlado e vigiado, e a utilização 'ótima' do tempo passou a ser determinante na metodologia utilizada". Até o lazer, a recreação, passou a ser formativa, através de estímulos ao corpo e ao espírito; a higiene física e mental transformou-se em sinônimo de lazer, conformando-se uma moral particular para o ócio.

Tomando como referente os pensamentos higienistas gestados na Europa, e com apoio do Estado (que medicaliza suas ações políticas), os médicos brasileiros desenham um novo modelo de homem no marco de um discurso normativo, disciplinador e moral. Disciplinador dos corpos, dos hábitos e dos indivíduos, tudo em nome da saúde. Nesse sentido, a disciplina tem, no Brasil, desde a segunda metade do século XIX, uma vinculação direta com a promoção da saúde física e mental, sendo privilegiadas as propostas pedagógicas de base anátomo-fisiológica (SOARES, 1994)

No país, a Educação Física tende a confundir-se em diversos momentos da história com as instituições médicas e militares, na medida que em diferentes momentos são estas instituições as que definem o caminho da educação física, delimitando o espaço e campo de conhecimento, tornando-a um valioso instrumento de ação e intervenção na realidade social do país (SOARES, 1994). A disciplina, o exercício físico, formam parte de um dispositivo mais amplo de regularização das populações aplicado pelos Estados, a partir da geração de instituições e promoção de discursos que vão penetrar no nível mais micro, no nível da subjetivação produzindo sujeitos que vão se responsabilizar, ao final, pelo seu próprio bem estar, pela sua própria saúde.

Esse contexto permite-nos compreender o fato de que, no século XX, o corpo tenha ascendido como valor de contemporaneidade, e os modos de subjetivação passaram por processos de somatização e exteriorização, o que significa, segundo Ortega e Zorzanelli, que o sentido de nós mesmos como indivíduos habitados por um espaço interno, formado pela biografia como fonte de individualidade, passa a ser definido em termos corporais e biomédicos. Nas palavras dos autores (2010, p. 75), "a linguagem por meio da qual os indivíduos tem descrito a si mesmos tem se baseado cada vez mais em termos médicos que se popularizam, fornecendo princípios de avaliação dos indivíduos para a gestão da própria saúde". 
Em conformidade com o exposto, podemos observar que Foucault se afasta da noção de dominação proposta por Marx. Para Foucault, o poder, as relações de sujeição efetivas são as que fabricam sujeitos ${ }^{6}$. Neste sentido, a sua proposta consiste, mais do que em estudar os grandes aparelhos de poder, em ver como este funciona sobre a base de diversas técnicas de sujeição, que fazem dos procedimentos de dominação a trama efetiva das relações de poder (FOUCAULT, 1999). Mais do que em termos repressivos, o poder tem caráter produtivo nos textos de Foucault, criando realidade, criando modos de relacionamento consigo mesmo. Nesse sentido, Foucault estabelece que não é a partir de construções ideológicas que a forma operativa do poder deve ser analisada. Pelo contrário, afirma que o poder exerce-se através de mecanismos sutis, através de instrumentos efetivos de formação e acumulação de saber, de métodos de observação, de técnicas de registro, de procedimentos de indagação e pesquisa (FOUCAULT, 1984).

\section{PIERRE BOURDIEU: O SER ESPORTIVO}

"O esporte, que nasceu dos jogos realmente populares, isto é, produzidos pelo povo, retorna ao povo, como a folkmusic, sob a forma de espetáculos produzidos para o povo" (BOURDIEU, 1983, p. 9).

Para Bourdieu, os estudos a respeito do esporte não devem ser realizados mediante analogias com os jogos das sociedades pré-capitalistas europeias. Pelo contrário, o autor afirma que o sistema de instituições e de agentes vinculados ao esporte tende a funcionar como um campo ${ }^{7}$ autônomo, pelo qual o importante é indagar a respeito do momento em que o esporte moderno se constitui como um campo de práticas especificas, dotado de suas lutas e regras próprias, e investido de toda uma cultura e competição específicas. Nas palavras do autor (1983, p. 2):

A história do esporte é uma história relativamente autônoma que, mesmo estando articulada com os grandes acontecimentos da história econômica e política, tem seu próprio tempo, suas próprias leis de evolução, suas próprias crises, em suma, sua cronologia especifica.

Afirma, adiante, que é nas grandes escolas reservadas às elites das burguesias inglesas onde se produz a passagem do jogo, tradicionalmente popular, à consolidação dos exercícios corporais, começando, assim, um processo de distinção caracterizado pelo incremento da racionalização,

\footnotetext{
${ }^{6}$ Uma questão a destacar é que Foucault sempre teve interesse na análise da conformação do sujeito tal como o conhecemos hoje. Nesse sentido, afirma que "o trabalho nos últimos vinte anos não foi analisar o fenômeno do poder nem elaborar os fundamentos de tal análise. Meu objetivo, ao contrário, foi criar uma história dos diferentes modos pelos quais, em nossa cultura, os seres humanos tornaram-se sujeitos" (Foucault, O sujeito e o poder, p. 231).
}

${ }^{7}$ Campo é definido por Bourdieu como conjunto das estruturas objetivas (BOURDIEU, 2007). 
destinada a consolidar um corpo de regulamentos específicos e um corpo de dirigentes especializados. Esse processo será acompanhado pela conformação de uma filosofia política do esporte, de base moral aristocrática, formulada sobre valores de coragem e virilidade. $\mathrm{O}$ que realmente está em jogo neste processo, afirma o autor, é a educação burguesa oposta à definição pequeno-burguesa e profissional.

O campo das práticas esportivas é um lugar de disputas pela imposição da definição não só da prática esportiva, como também do corpo legítimo e dos seus usos legítimos. Nessa perspectiva, a Educação Física, enquanto disciplina escolar, conforma o resultado da luta entre duas definições de usos do corpo, enquanto hábitos esportivos: por um lado, a ênfase dada à educação, no esforço e na retidão; pelo outro, no hedonismo e privilégio da natureza, reduzindo a educação do corpo à educação do físico (BOURDIEU, 1983).

Em consonância com o exposto, o autor afirma que a mesma percepção do corpo, do próprio corpo, é reflexo da incorporação das classificações que posicionam o sujeito frente à comprovação da distância entre o corpo real e o corpo legitimo. As propriedades corporais, como alto/baixo, grande/pequeno, masculino/feminino, se organizam em sistemas sociais de classificação, que são incorporados e aprendidos através de categorias de percepção. Nesse sentido, a representação social do próprio corpo resulta da aplicação de um sistema de classificação social cujo princípio regulador é o mesmo que dos produtos sociais aos quais se aplica. $\mathrm{O}$ corpo socialmente objetivo é um produto social e suas propriedades distintivas dependem das condições sociais de produção (BOURDIEU, 1986).

Nesse sentido, a relação com o próprio corpo é uma dimensão privilegiada do habitus que distingue as classes populares das classes privilegiadas, assim como no interior destas distingue frações separadas por todo o universo de um estilo de vida. As práticas esportivas adotadas são disposições em relação ao esporte, interiorizadas nos sujeitos em forma de habitus, operando como conhecimento prático que o habilita para atuar no seu entorno mais próximo. A interiorização do habitus no campo esportivo está, então, na base do que podemos chamar um estilo de vida esportivo.

Os habitus são produto de trajetórias, são construções históricas. A experiência num mundo que se apresenta como evidente supõe um acordo entre as disposições dos agentes e as expectativas do campo no qual estão inseridos. É assim que as caraterísticas do próprio campo esportivo fazem com que a oferta de práticas e consumos esportivos propostos num dado momento do tempo se 
ajuste permanentemente com a demanda dos interesses e valores dos participantes potenciais. Nesse sentido, Bourdieu (1983, p. 13) afirma que

os interesses e valores que os praticantes saídos das classes populares e médias trazem consigo para o exercício do esporte se harmonizam com as exigências correlativas da profissionalização, tanto da racionalização da preparação (treino) quanto da execução do exercício esportivo imposta pela busca da maximização da eficácia específica (medida em "vitórias", "títulos", e "records") busca que é ela mesma correlativa do desenvolvimento de uma indústria -privada ou pública- do espetáculo esportivo.

Por outro lado, esse ajustamento entre as disposições incorporadas às posições no espaço social, é assegurado por toda uma série de mecanismos sociais, que oferecem uma experiência quase mágica do mundo social, ou seja, criam sensação de conformidade com o lugar ocupado no campo. Os agentes são investidos de uma potencialidade, um desejo de ser de determinado modo, segundo o campo e as regras do próprio jogo. Esse desejo reflete a violência simbólica que toda incorporação de habitus implica. Nesse sentido, a incorporação de um habitus esportivo constitui a incorporação, no corpo, das relações de dominação, que têm sempre uma dimensão simbólica (BOURDIEU, 2007).

Produto da incorporação de uma estrutura social sob a forma de uma disposição quase natural, frequentemente dotada de todas as aparências do que é inato, o habitus é uma energia potencial, a força dormente de onde a violência simbólica extrai sua eficácia. Os agentes encontram-se localizados no interior de uma ordem especifica, e, ao mesmo tempo, esse lugar está nos sujeitos sob a forma de habitus, o qual permite que se movimentem na vida cotidiana com a ilusão de se sentir como "peixes na água", antecipando-se praticamente às situações do entorno. Nas palavras do autor (BOURDIEU, 2007, p. 166):

Se o agente possui uma compreensão imediata do mundo familiar, isso ocorre porque as estruturas cognitivas aplicadas por ele constituem o produto da incorporação das estruturas do mundo no qual ele age, e também porque os instrumentos de construção empregados para conhecer o mundo são construídos pelo mundo.

Diante da aceitação dos limites impostos, vividos de forma "natural", ou seja, os dominados aceitam implicitamente sua dominação. A desigualdade toma, então, um caráter corporal, na medida que a classe social em Bourdieu não se define simplesmente pela posição nas relações de produção, e sim pelo habitus de classe que "normalmente" é associado a essa posição (BOURDIEU, 1979). Em termos gerais, a probabilidade de "gostar" de uma prática esportiva depende do capital econômico e cultural, isto por intermédio da afinidade que se estabelece entre as disposições estéticas associadas a determinada posição no espaço social e os lucros que em função destas 
disposições parecem prometidos para os diferentes esportes. Isso permite-nos compreender por que as classes médias se dedicam intensivamente à ginástica, o esporte ascético por excelência, na medida em que se reduz a uma espécie de treinamento pelo treinamento (BOURDIEU, 1983).

Finalmente, preocupado com a análise da passagem do esporte como prática de elite para o esporte como espetáculo produzido por profissionais e destinado ao consumo de massa, Bourdieu afirma que um dos determinantes foi a transformação dessas práticas em objeto de lutas políticas entre as instituições organizadas para conquistar politicamente as massas, sobretudo a população operária. $\mathrm{O}$ esporte transformou-se, assim, num objeto de luta política. Essa passagem da elite às massas vai ser acompanhada da modificação das funções dos próprios esportistas e das mesmas práticas, em função da transformação das expectativas e exigências do público. O esporte aparece para as classes populares em forma de mercadoria, principalmente depois que as competições esportivas se tornaram uma das medidas da força relativa das nações, ou seja, uma disputa política. Isso gerou uma ruptura entre prática e consumo, extensão ou público que tendeu ao reino dos profissionais puros, o que significa que ficam excluídos da produção, sendo consumidores passivos (BOURDIEU, 1983).

Trabalharemos a seguir sobre essa questão, a partir da proposta de Thompson a respeito do papel das mídias nessa ruptura.

\section{ESPORTE E IDEOLOGIA DESDE A PROPOSTA D THOMPSON}

"Estudar a ideologia é estudar as maneiras como o sentido serve para estabelecer e sustentar relações de dominação" (THOMPSON, 1999, p. 76)

No início do trabalho, apresentamos uma das concepções de ideologia que Thompson identifica na obra de Marx. Mas ele vai tomar como referência para o seu desenvolvimento teórico uma concepção que identifica como latente, e que descreverá da seguinte forma (1990, p. 58):

[...] sistema de representações que servem para sustentar relações existentes de dominação de classe através da orientação das pessoas para o passado em vez de para o futuro, ou para imagens e ideias que escondem as relações de classe e desviam da busca coletiva de mudança social.

Thompson vai se mostrar interessado nessa concepção de ideologia dos trabalhos de Marx, na medida que tem a ver com os símbolos e slogans, com as costumes e tradições, o que permite pensar, como afirma o autor, nos símbolos usados e transformados em contextos sociais específicos. 
Porém, a exemplo de Foucault e Bourdieu, Thompson critica a noção de dominação pensada só em termos de classe social. $\mathrm{O}$ autor afirma que as relações de classe são apenas uma forma de dominação, existindo outras sempre que relações estabelecidas de poder (em termos de capacidade social ou institucional conferida aos atores para tomar decisões) sejam sistematicamente assimétricas. Existe dominação, então, quando grupos particulares de agentes possuem poder de uma maneira permanente e em grau significativo. Podemos identificar relações de dominação nas relações de gênero, idade ou raça, entre outras.

Por outro lado, assim como Foucault destaca o caráter produtivo do poder, afirmando que o poder disciplinador, favorável à burguesia, constrói sujeitos favoráveis para a reprodução do capitalismo, Thompson vai estabelecer que as formas simbólicas e o sentido por elas mobilizado são constitutivos da realidade social ${ }^{8}$, com a qual estão ativamente envolvidos tanto em criar como em manter as diferentes relações de dominação.

A proposta de Thompson consiste em analisar os conteúdos específicos dentro dos quais as formas simbólicas são produzidas e recebidas, mas sempre considerando o contexto específico de interação, para estabelecer de que maneira o sentido pode sustentar relações de dominação. Podemos afirmar, então, que o sentido das formas simbólicas que deram sustento à Educação Física, e que temos detalhado nas partes anteriores, levando-nos à ideia de que o destino do homem na Terra já não depende da ordem estabelecida, mas sim das suas qualidades biológicas ${ }^{9}$, tendeu a justificar e naturalizar as desigualdades existentes na época.

No caso do Brasil, afirma Soares (1994), a Educação Física, tal como figura nos congressos médicos e propostas pedagógicas, aparecerá colada com os ideais eugênicos da regeneração e embranquecimento da raça. Na segunda década do século XIX, no marco de um projeto de eugenização da população brasileira, a Educação Física passou a ser valorizada e a aparecer em publicações que tratavam de questões de saúde em geral, de moral e de educação. A cargo desse empreendimento, os higienistas, incumbidos de pensar a educação das elites, deviam associar a Educação Física à educação sexual, transformando a homens e mulheres em produtores parciais e, ao mesmo tempo, vigilantes da sua própria raça. Podemos afirmar que as propostas pedagógicas da educação física, nas suas origens, o sustento do treinamento esportivo vão estar carregadas de um

\footnotetext{
${ }^{8}$ Posição que o afasta, mais uma vez, da concepção econômico-determinista de Marx, afirmando que este tende a menosprezar o papel das formas simbólicas na construção da realidade social.

${ }^{9}$ Convém destacar, quanto a isso, a importância do princípio desenvolvido na teoria da evolução de Darwin, segundo a qual as espécies que sobrevivem são as mais aptas, justificando as desigualdades raciais sobre a base de causas biológicas. Sobre esta ideia vão se desenvolver os conceitos de competição e concorrência (Soares, 1994).
} 
sentido que sustenta e reproduz relações de poder desiguais em termos de raça, contribuindo na justificação das desigualdades econômicas, políticas e sociais.

Uma pergunta sobre a qual queremos avançar agora é: Como se alcança, a partir dessa pedagogia, aplicada sobretudo nas escolas que educavam a uma elite branca na segunda metade do século XIX no Brasil, uma prática massiva, representada na imagem que descrevíamos no início deste trabalho?

Para responder a essa pergunta é preciso pensar a respeito do papel que o desenvolvimento dos meios massivos de comunicação tem tido na massificação do esporte como pratica cultural ${ }^{10}$. Para tanto, lançaremos mão de um dos conceitos mais importantes desenvolvido por Thompson (1990), que ele chama mediação da cultura moderna. O autor afirma que as sociedades modernas tornam-se cada vez mais mediadas por mecanismos e instituições da comunicação de massa, e que, portanto, toda análise da ideologia deve se orientar ao conteúdo e recepção em cada contexto particular das mensagens da mídia.

Com a aparição, na Europa do fim do século XV e início do século XVI, de um conjunto de instituições ligadas à valorização econômica da forma simbólica, e com o consequente desenvolvimento técnico do instrumental para sua ampla circulação no tempo e no espaço, a cultura passa a ser mediada cada vez mais pelos mecanismos de comunicação de massa, entendida como a "produção institucionalizada e a difusão generalizada de bens simbólicos através da transmissão e do armazenamento da informação/comunicação" (THOMPSON, 1990, p 288). Esse fenômeno implica na ruptura fundamental na forma de comunicação entre o produtor e o receptor, uma vez que, desta forma, os receptores têm pouca possibilidade de contribuir no curso do conteúdo e no processo de comunicação.

Diante do exposto, devemos pensar que a competição esportiva, presente já nos séculos passados como entretenimento, se torna acessível a uma maior parte da população, e podemos dizer que se torna massiva, a partir do momento em que se entrelaça com os meios de comunicação. Já no último quartel do século XIX, no quadro de preocupações pelo saneamento e salubridade das cidades, e a partir das influências europeias ilustradas em revistas e jornais da época, foi se construindo um novo modelo de homem, agora mais inquieto com a estética corporal. Lentamente, começaram a ser valorizados os tipos físicos masculinos fortes, com musculatura marcada. Posteriormente, no início do século XX, nota-se a crescente valorização da ginástica, além do remo,

\footnotetext{
${ }^{10}$ Não é nosso intuito dar uma resposta cabal e fechada à questão da massificação do esporte no país, somente refletir a respeito da importância que o desenvolvimento dos meios de comunicação pode ter tido.
} 
da natação, do ciclismo, e os atletas começaram a ser reverenciados por suas formas físicas, sua musculatura desenvolvida, seu vigor e saúde (ANDRADE DE MELO, 2011).

Nos anos 1970, a novidade da articulação entre ciência e estética constituiu um dispositivo efetivo na promoção de um estilo de vida saudável em termos de alimentação e práticas para aperfeiçoar o corpo. A popular imagem de Jane Fonda, acompanhada da proposta do modelo do Dr. Keneth Cooper, foram recebidos com entusiasmo por uma jovem classe profissional que se encontrava em ascensão e ansiosa de realização pessoal (LANDA, 2011).

O corpo, nesse transcurso, começa ser ilustrado, nos meios de comunicação, como objeto valorizado economicamente. Surgem e proliferam os produtos destinados a transformar a aparência física. Podemos dizer, seguindo a proposta teórica de Thompson, que os meios massivos de comunicação serão fundamentais na conformação do corpo-símbolo economicamente valorizado e significado. As imagens corporais de atores no cinema serão utilizadas para aumentar o valor econômico de um conjunto de produtos destinados a manter um estilo de vida saudável e ativo. A autodisciplina, o exercício físico rotineiro, a preocupação com a saúde e beleza, constituem-se como responsabilidades de cada pessoa.

\section{CONSIDERAÇÕES FINAIS}

Iniciamos este trabalho procurando compreender como é possível a conformação do que chamamos um "jeito de ser esportivo" característico dos sujeitos citadinos atuais. O questionamento leva-nos a pensar a respeito da construção dos sujeitos nas sociedades modernas. Para dar conta dessa análise, tomamos três modelos teóricos que apresentam diferentes propostas para compreender como operam os processos de subjetivação para assegurar a eficácia das diversas relações de dominação.

Nessa direção, as concepções de ideologia expostas nos diferentes trabalhos de Marx consolidam-se como referências inquestionáveis para elaborações teóricas posteriores. Três autores (Foucault, Bourdieu e Thompson) se afastam da concepção negativa do poder presente nos trabalhos do autor clássico, interessados mais nas suas formas positivas de operar, entendendo-o como produtor de realidade. Nesse sentido, Foucault estabelece que os instrumentos necessários para a análise do poder não devem ser deduzidos da economia. O poder não é aquilo que reprime, mas sim este que se exerce através da formação e acumulação de saberes. Mais que analisar construções ideológicas, o autor propõe estudar os aparatos de saber organizados e postos em circulação no exercício do poder. Nesses termos, para compreender o estilo de vida esportivo, 
dirigimo-nos aos discursos de saber que se consolidaram na Educação Física, enfatizando a eficácia do mecanismo disciplinador do poder na subjetivação das normas sociais.

Da mesma forma que Foucault, Bourdieu discute a noção de ideologia marxista, afirmando que o efeito da violência simbólica nos corpos não é umas simples reprodução mental suscetível de ser combatida apenas pela força de ideias consideradas verdadeiras numa época, uma vez que a eficácia das diferentes dominações deve-se a uma crença tácita e prática tornada possível pela domesticação dos corpos. Porém, Bourdieu não deixa de considerar a importância das condições materiais de existência na conformação dos habitus, criticando assim Foucault por subestimar a pressão ou opressão dos condicionamentos impostos pelas estruturas econômicas e sociais e dos mecanismos por meio dos quais elas se reproduzem. O que está na origem de um estilo de vida esportivo, de um jeito de ser esportivo desde a perspectiva de Bourdieu, é a interiorização na forma de habitus, de um conjunto de disposições segundo as diferentes posições no campo esportivo.

Thompson, finalmente, reivindica a ideologia em termos negativos, na relação que as formas simbólicas têm nos diferentes contextos de interação, com as relações assimétricas de poder. Tal qual os outros dois autores, Thompson destaca o papel da cultura na produção e reprodução das dominações. Afastado de Foucault na sua forma de conceber a interiorização das formas simbólicas, Thompson atribui ao sujeito um papel mais ativo na produção de sua subjetivação, sendo considerado como um receptor ativo. O fenômeno da massificação do esporte, e, assim, das formas simbólicas que fazem a valorização positiva dos estilos de vida esportivos, deve ser analisado no contexto de desenvolvimento da comunicação de massa, o qual tem aumentado significativamente o raio de operação da ideologia, possibilitando que as formas simbólicas sejam transmitidas para audiências mais extensas e dispersas no espaço e no tempo.

Apesar das diferenças na hora de compreender o desenvolvimento do fenômeno esportivo, as três perspectivas analisadas levam-nos à conclusão de que devemos, como pesquisadores sociais, questionar a obviedade dessas práticas que vemos dia a dia nos contextos urbanos atuais, permitindo-nos analisar o caráter político da prática esportiva na conformação e reprodução das relações de poder. 


\section{REFERÊNCIAS}

ANDRADE DE MELO, V. O corpo esportivo nas searas tupiniquins: panorama histórico. In: DEL PRIORE, M.; AMANTINO, M. (Org.). História do corpo no Brasil. São Paulo: Editora Unesp. 2011, p. 507-529.

BOURDIEU, P. Meditações pascalinas. Rio de Janeiro: Bertrand Brasil, 2007.

BOURDIEU, P. "Notas provisionales sobre la percepción social del cuerpo. In Materiales de Sociología Crítica. Madrid: La Piqueta, 1986.

BOURDIEU, P. Como é possível ser esportivo? In: BOURDIEU, P. Questões de Sociologia. Rio de Janeiro: Marco Zero, $1983 . \quad$ p. 136-153. Disponível em: <http://www.pgedf.ufpr.br/downloads/Artigos\%20PS\%20Mest\%202015/ELS/WM-

Como\%20\%C3\%A9\%20posss\%C3\%ADvel\%20ser\%20esportivo\%20P.\%20Bourdieu.pdf> Acesso em: 12 dez. 2015.

BOURDIEU, P. La distinción: Criterio y bases sociales del gusto. Madrid: Ed. Taurus, 1979.

FERNANDEZ VAZ, A. Treinar o corpo, dominar a Natureza: notas para uma análise do esporte com base no treinamento corporal. Cadernos Cedes, ano XIX, n ${ }^{\circ 8}$, 1999. Disponível em: $<\mathrm{http}: / / w w w . s c i e l o . b r / p d f / c c e d e s / v 19 n 48 / v 1948 a 06 . p d f>$. Acesso em: 14 jul.2015.

FOUCAULT, M. Em Defesa da Sociedade: Curso no Collège de France (1975-1976). 4a ed. São Paulo: Martin Fontes, 1999.

FOUCAULT, M. Vigiar e punir: história da violência nas prisões. 2a ed. Petrópolis, RJ: Editora Vozes, 1987.

FOUCAULT, M. Microfísica do poder. 4a ed. Rio de Janeiro: Edições Graal, 1984.

LANDA, M. I. Las tramas culturales del Fitness en Argentina: los cuerpos activos del ethos empresarial emergente. 2011. 344 f. Tese (Estudios de Doctorado en Teoría Literaria y Literatura Comparada) Facultad de Filosofía y Letras, Universitat Autónoma de Barcelona, Barcelona, 2011.

MARX, K. Contribuição a crítica da Economia Política.São Paulo: Editora Expressão Popular, 2008.

Disponível

em: $<$ http://www.histedbr.unir.br/downloads/3782_contribuicao_a_critica_da_economia_politica.pdf $>$. Acesso em: 10 jul. 2015 
ORTEGA, F.; ZORZANELLI, R. A saúde como salvação: contexto cultural de ascensão do corpo como valor na contemporaneidade. In ORTEGA, F.; ZORZANELLI, R. Corpo em evidência: a ciência e a redefinição do humano. Rio de Janeiro: Civilização Brasileira. 2010, p. 63-95.

SOARES, C. L Educação física: raízes europeias e Brasil. 1a ed. Campinas, SP: Editora Autores Associados, 1994.

THOMPSON, J. Ideologia e cultura moderna: Teoria social crítica na era dos meios de comunicação de massa. 5a ed. Petrópolis, RJ: Editora Vozes Ltda, 1990.

TORRI, D. Teoria Crítica do Esporte: atividade, disputas e interpretações. 2008. 102 f. Tese (Mestrado em Educação) Universidade Federal de Santa Catarina, Centro de Ciências da Educação. Disponível em: <http://repositório.ufsc.br/handle/123456789/92043>. Acesso em: 18 jul. 2015.

\title{
ANALYSIS OF IDEOLOGY CONCEPTS, DISCIPLINE AND HABITUS FROM SPORT MASSIFICATION IN BRAZIL
}

\begin{abstract}
The sport - that is, the body training - embodies values such as discipline, energy and rhythm; values that can be identified in promoting economic productivity. From the second half of the twentieth century, in a context of industrialization and urbanization of the country, the sports activity begins to turn into a massive phenomenon of consumption in free time. In large cities, especially Rio de Janeiro and São Paulo, the sports activity becomes a hallmark of modernizing character, focused on representations and hygiene and health standards that have been absorbed by various sectors of society.

The work followed the main objective to discuss the institutionalization of physical education as a compulsory subject in high school, as well as discussing about the massification process of sports practices in urban contexts of the country. is placed as second objective, to present and discuss, from the above phenomenon, the scope and limitations of the concept of ideology. In this sense, we present the theoretical proposals Thompson about the ideology and the media, the concept of habitus of Bourdieu and Foucault discipline.
\end{abstract}

Key-words: Sport. Ideology. Discipline. Habitus. 